\title{
The effect of feeding ochratoxin A-contaminated diet to broiler breeding flocks on the chickens performance*
}

\author{
Warsaw Agricultural University, \\ ${ }^{1}$ Department of Poultry Breeding, \\ ${ }^{2}$ Department of Poultry Diseases \\ Ciszewskiego 8, 02-786 Warsaw, Poland
}

J. Niemiec ${ }^{1,3}$, M. Stępińska ${ }^{1}$, J. Riedel ${ }^{1}$ and P. Szeleszczuk ${ }^{2}$

\begin{abstract}
The experiment was conducted on three breeding flocks of broiler hens Cobb, Hubbard and Ross 60 chickens each. Each flock was divided into an experimental and control group ( 30 hens and 4 roosters). The chickens in the experimental group were fed for 4 weeks with a feed containing $0.5 \mathrm{mg}$ ochratoxin $\mathrm{A} / \mathrm{kg}$, whereas the feed for the control group was not contaminated. The hatched healthy chickens from all groups were reared to day 49 of life. On day 49, 5 males and 5 females from each group were slaughtered and carcass analysis was performed.

Feeding ochratoxin A-contaminated feed to broiler breeding flocks had a negative influence on the body weight, carcass yield and meat percentage of offspring. Broilers from parents fed the contaminated feed showed $0.1 \mathrm{~kg}$ worse feed utilization per $\mathrm{kg}$ body weight gain. No effect of feeding contaminated feed to the breeding flocks was found on the mortality of the broilers.
\end{abstract}

KEY WORDS: ochratoxin A, broiler breaders, broiler chickens

\section{INTRODUCTION}

In the climatic conditions of Poland, ochratoxin A is a mycotoxin frequently detected in cereals (Chełkowski and Goliński, 1982). Feeding laying hens a feed containing ochratoxin A reduces feed intake, body weight, and egg yield. The morphological traits of eggs also deteriorate, as does the quality of the hatched chickens (Scholtyssek et al., 1987; Niemiec et al., 1990).

\footnotetext{
* Supported by the State Committee for Scientific Research, Grant No. 3P $06 Z 00423$

${ }^{3}$ Corresponding author: e-mail: niemiecj@alpha.sggw.waw.pl
} 
The objective of this study was to determine the effect of feeding broiler breeding flocks a feed contaminated with ochratoxin A on the performance of offspring.

\section{MATERIAL AND METHODS}

The experiment was conducted on three breeding flocks of broiler hens: Cobb, Hubbard and Ross (60 chickens each) maintained on litter. In each flock, the birds were divided into two groups: the control (C) and experimental (D) with 30 hens and 4 roosters each. For 4 weeks, groups $\mathrm{C}$ were fed a typical diet for breeding flocks, whereas groups $\mathrm{D}$ received a diet of the same composition but containing ochratoxin A (OA), produced by the method of Schindler and Nesheim (1970) by infecting wheat grain with a strain of the fungus, Aspergillus ochraceus. Meal made from the contaminated wheat contained $98 \mathrm{mg}$ OA per $\mathrm{kg}$. This meal was added to diet $\mathrm{D}$ to a final concentration of $0.5 \mathrm{mg}$ ochratoxin $\mathrm{A}$ per $\mathrm{kg}$ of diet, whereas the same amount of uncontaminated wheat meal was added to diet $\mathrm{C}$.

After 14 days of feeding the flocks with these diets, collection of eggs for hatching was begun. The hatched healthy chickens from each group (50 per group) were reared to day 49 of life. The chickens were fed standard broiler diets. During this period, the body weight was recorded on days 1,21 and 49 of life, as were feed consumption and mortality. On day 49 of life, 5 males and 5 females from each group were slaughtered and carcass analysis was performed.

The results were subjected to statistical analysis separately for each sex, using two-way analysis of variance with interactions calculated by the least square method (SPSS 12.0, GLM procedure).

\section{RESULTS AND DISCUSSION}

Feeding breeding flocks with an OA-contaminated diet significantly affected the body weight of the hatched female chickens, but had no effect on the body weight of the hatched males (Table 1). The body weight of one-day-old female chickens from the flocks fed the contaminated diet was higher compared with the control groups. The weights of the control and experimental one-day old males were similar. The higher body weight of the female chickens from the flocks fed the contaminated diet may have resulted from delayed resorption of the yolk sac (Niemiec et al., 1990). The absence of differences among males may suggest their lesser sensitivity to OA in comparison with females. Feeding the contaminated diet to the breeding flock also had a significant effect on the body weight of the offspring during growth (Table 1). On day 21 of life, both the males and females from parents in flocks fed the OA-contaminated feed were lighter than 
in the control group. In males, the effect of the parental flock was significant, in females, statistically insignificant. On day 49 of life, the flock effect on the body weight of both males and females was significant, and the weight of males was lower in groups from parents fed OA-contaminated feed, whereas in respect to the females, the effect of feeding parents was not significant. In our previous studies (Niemiec et al., 1988) significantly inferior performance of broiler flocks fed OA-contaminated feeds in comparison with controls was also found. The study of Niemiec et al. (1990) shows that the inferior performance of broilers from parents fed OA-contaminated feed is due to reduced immunity, liver and kidney damage, and consequently, poorer growth. The passing of ochratoxin A into eggs, shown by these authors, has a direct influence on the development and quality of the chickens that hatch from these eggs. Despite no significant interaction found between flock and feeding, it seems that not all of the studied lines of chickens equally reacted to the presence of $\mathrm{OA}$ in the feed (Table 1).

Table 1. The effect of feeding OA-contaminated feed to broiler breeder flocks on broiler body weight, g, and results of slaughter analysis, \%

\begin{tabular}{|c|c|c|c|c|c|c|c|c|c|c|}
\hline \multirow{2}{*}{ Traits } & \multirow{2}{*}{ Sex } & \multicolumn{3}{|c|}{ Experimental group } & \multicolumn{3}{|c|}{ Control group } & \multirow{2}{*}{ RMSE } & \multicolumn{2}{|c|}{ Significance $^{1}$} \\
\hline & & Cobb & Hubbard & Ross & Cobb & Hubbard & Ross & & flock & diet \\
\hline \multirow{2}{*}{$\begin{array}{l}\text { Body weight, } g \\
1^{\text {st. day }}\end{array}$} & के & 47.2 & 37.6 & 45.4 & 47.7 & 38.8 & 45.5 & 3.2 & $<0.001$ & ns \\
\hline & 우우 & 47.6 & 41.1 & 43.6 & 46.4 & 38.5 & 42.7 & 3.2 & $<0.001$ & $<0.00$ \\
\hline \multirow{2}{*}{21 day } & $\hat{\sigma} \widehat{\partial}$ & 553 & 500 & 554 & 624 & 551 & 661 & 55.9 & $<0.01$ & $<0.00$ \\
\hline & 우우 & 550 & 500 & 522 & 578 & 506 & 567 & 44.5 & ns & $<0.00$ \\
\hline \multirow{2}{*}{49 day } & ठิ & 2936 & 2471 & 3133 & 2946 & 2734 & 3274 & 241 & $<0.001$ & $<0.01$ \\
\hline & 우우 & 2494 & 2211 & 2509 & 2405 & 2218 & 2514 & 157 & $<0.001$ & $\mathrm{~ns}$ \\
\hline \multirow{2}{*}{ Carcass yield, \% } & $\widehat{\partial} \widehat{\partial}$ & 72.9 & 71.6 & 74.4 & 74.1 & 74.8 & 74.8 & 1.3 & ns & $<0.01$ \\
\hline & 우우 & 74.2 & 74.1 & 73.9 & 74.9 & 74.3 & 75.0 & 1.5 & ns & $\mathrm{ns}$ \\
\hline \multirow{2}{*}{ Breast muscle, $\%$} & $\widehat{\partial \partial}$ & 24.1 & 24.5 & 26.4 & 24.9 & 25.7 & 26.9 & 2.0 & ns & $\mathrm{ns}$ \\
\hline & 우우 & 25.2 & 24.6 & 25.5 & 26.1 & 25.6 & 26.8 & 1.7 & ns & ns \\
\hline \multirow{2}{*}{ Leg muscle, $\%$} & $\widehat{\partial} \widehat{\partial}$ & 21.0 & 19.8 & 20.8 & 21.5 & 20.7 & 21.6 & 1.1 & ns & $\mathrm{ns}$ \\
\hline & 우우 & 18.2 & 18.5 & 18.8 & 19.5 & 19.9 & 19.7 & 1.5 & ns & $\mathrm{ns}$ \\
\hline
\end{tabular}

${ }^{1}$ interaction between flock and diet was not significant for all traits

RMSE - root of the mean square error; ns - non-significant

No effect of feeding was found on the health of the breeding flocks. During the entire period of rearing, mortality in all of the groups was similar and equaled about $1.5 \%$. Feed utilization per kg body weight gain in all experimental groups was worse by about $0.1 \mathrm{~kg}$ than in the control groups. Slaughter analysis indices, as well as dressing percentage, breast and leg muscle share (\%) were higher in the group of broilers descended from parents fed uncontaminated feed (Table 1). 
Similar results were obtained by Niemiec et al. (1988). In this study, the differences in the dressing percentages between chickens from parents fed OAcontaminated or control feeds were mostly not statistically significant, but in industrial production, they would have a measurable economic effect.

\section{CONCLUSIONS}

Feeding broiler breeding flocks with ochratoxin A-contaminated feed has a negative impact on the quality of chickens and their performance.

\section{REFERENCES}

Chełkowski J., Goliński P., 1982. Mycotoxins and toxinogenic fungi in mixed feeds and their cereal components. Proceedings of V International Symposium of Mycotoxins and Phycotoxins. Wien, pp. $67-71$

Niemiec J., Borzemska W., Roszkowski J., Karpińska E., 1990. Influence of ochratoxin A contaminated feed on chick embryogenesis. Arch. Geflügelk. 54, 70-73

Niemiec J., Scholtyssek S., Bauer J., 1988. Ochratoxin A im Broilerfutter: Einfluss auf die Gewichtsentwicklung und Rückstande im Gewebe. Arch. Geflügelk. 52, 163-168

Schindler A. F., Nesheim S., 1970. Effect of moisture and incubation time on ochratoxin A production by isolate of Aspergillus ochraceus. J. Assn. Anal. Chem. 53, 89-91

Scholtyssek S., Niemiec J., Bauer J., 1987. Ochratoxin A im Legehennenfutter. 1. Mitteilung: Einfluss auf Legeleistung und Eiqualität. Arch. Gefügelk. 51, 234-240

\section{STRESZCZENIE}

\section{Wpływ żywienia stad reprodukcyjnych kur typu mięsnego mieszanką skażoną ochratoksyną A na wyniki odchowu brojlerów}

Doświadczenie przeprowadzono na 3 stadach kur reprodukcyjnych Cobb, Hubbard i Ross, po 60 kur w grupie. Każde stado podzielono na grupę doświadczalną i kontrolną (30 kur i 4 koguty). Kury w grupie doświadczalnej żywiono przez 4 tygodnie mieszanką zawierającą 0,5 mg ochratoksyny $\mathrm{A} / \mathrm{kg}$, a w grupie kontrolnej paszą nie skażoną. Wyklute zdrowe pisklęta z obydwóch grup odchowywano do 49 dnia życia. W 49 dniu z każdej grupy ubito po 5 kur i 5 kogutów i wykonano analizę rzeźną.

Żywienie stad reprodukcyjnych kur paszą skażoną ochratoksyną A miało ujemny wpływ na masę ciała brojlerów, wydajność rzeźną oraz udział mięśni w tuszce. Brojlery pochodzące po kurach z grup doświadczalnych miały o $0,1 \mathrm{~kg}$ gorsze wykorzystanie paszy na kg przyrostu masy ciała. Nie stwierdzono wpływu żywienia stad reprodukcyjnych na zdrowotność brojlerów. 